\title{
THE ENLARGEMENT POLICY OF THE EUROPEAN UNION AND ITS LINK WITH THE EXTERNAL DIMENSION OF HUMAN RIGHTS POLICY WITH SPECIAL EMPHASIS ON THE TURKISH CASE
}

Çiğdem NAS*

\begin{abstract}
One of the primary themes which occupies the agenda of the European Union is the issue of enlargement. After the accession of Austria, Finland, and Sweden in 1995, the Union is faced with the task of making a decision concerning the membership of applicant Central, Eastern, and Southern European countries. Following, the conclusion of the 1996 Intergovemmental Conference, the enlargement negotiations with Cyprus and possibly Poland, Hungary, and the Czech Republic, are due to start. (i.e. Malta withdrew its application following the change of government in the general electrions of 26.10.1996). In this context, Turkey occupies a unique position. It concluded an association agreement with the European Community in 1963 which is much earlier than the other applicant countries. However, especially after 1989, Turkey has fallen behind in the list of potential members to the Union. While the accession of Cyprus, and the Central and Eastern European Countries is only a matter of time, Turkey's membership does not seem likely to happen. One of the main arguments put forth against the Turkish application is Turkey's poor human rights record. In this context, the article tries to explore the significance of human rights considerations in the European Union's enlargement process by way of referring to the conclusions of the European Council meetings, and attempts at stressing the importance of improving the human rights situation in Turkey in order to develop Turkey-European Union relations.
\end{abstract}

The European Union (EU) is currently going through a particularly remarkable period of its history. The countdown to the Economic and Monetary Union (EMU) which is envisaged in the Treaty on European Union (TEU) has already begun; it is to take effect on 1.1.1999, if everything goes according to plan. Most of the member states are making their last efforts to meet the EMU criteria while some are, voluntari- 
ly or not, excluded from it for the time being. Another equally important development is the Intergovernmental Conference (IGC) which was convened on March 29, 1996 and is to reach its conclusion during the Amsterdam meeting of the European Council in June 1997. The IGC was foreseen in the TEU for the purpose of reviewing and making the necessary amendments to the Treaty itself. The current significance of the IGC lies in the fact that it is the main platform to pave the way for the future enlargement of the Union. The necessary institutional changes, adjustment of the decision-making mechanism, strengthening of policies, in particular the common foreign and security policy, and increasing the transparency of EU institutions are among the priorities of the IGC.

The streamlining of decision-making and adaptation of the institutional mechanism must be decided upon before the EU expands to include at least 19 and at most 27 members. Without a successful conclusion of the IGC enlargement will put the EU mechanism and the achievements to date at risk. Now that we are approaching the end of the IGC and the new revised treaty is in sight, the dice is about to be cast: Which applicant countries are to become future members of the Union and when?

The aim of this paper is to explore the link between the enlargement policy of the EU and its external human rights policy. This connection is particularly relevant for Turkey due to its much criticized human rights record. The main argument of this paper is that the success of the Turkish application is directly related to the improvement of democracy and human rights in Turkey which in turn is an indicator of the political and economic development of the country. Therefore, a Turkey where human rights violations are an exception rather than the norm and democracy is unhindered, coincides with a Turkey which is economically, politically and socially fit to become a member of the Union.

\section{The Future Enlargement of the EU}

To end the divide which seperated Europe into two rival blocs during the Cold War, the EU has shown its preference for the accession of the Central and East European Countries (CEEC), particularly, Poland, Hungary and the Czech Republic, to the Union. Strategic, political, and economic motives lie behind the inclination to include these countries into the European integration process. Bringing back the CEECs into the European system of values is seen as vital to guarantee peace and security in the region.

The Union is a role model for the recently liberalized CEECs which have all expressed their desire to become EU members. The EU is faced with a dilemma: to make a decision concerning the applicant countries: to include some whilst excluding 
others. This decision necessitates the definition of Europe's borders which is a most difficult endeavor considering the ambiguity of the concept of Europe and the hopeless task of defining what 'being European' means. The task confronting the EU is to define a "policy for Europe".

The EU is walking on a tight rope. Not all of the applicant countries are fit to become members of the EU. The accession of those countries which are economically and politically weaker would disable the working of the Union. However, leaving these countries out would create instability and disillusionment in Europe's periphery and marginalization of some countries. Keeping in mind the fact that those who are left out will be those with the most serious problems, exclusion would affect them more adversely than those which are relatively better off.

It is likely that the EU will respond to this challenge by associating with these countries in various ways according to their levels of development. Not all of the applicant countries will become members of the EU. However, the Union will develop different forms of cooperation and partnership with the "not-good-enough" countries. A recent case is the customs union between Turkey and the EU.

\section{Recent Evolution of the Enlargement Process}

The most recent enlargement of the EU took place on 1.1.1995. Three former EFTA members, Austria, Finland and Sweden, acceded to the EU. These countries were fully fledged Western democracies with no apparent record of human rights violations. The economic and social indicators of these countries were in line with, and even higher than the EU average.

After the enlargement involving the three former EFTA countries, which is mainly seen as an advantage for the EU, the possibility of the membership of the CEECs rose to the top of the agenda. Special association agreements, called the 'Europe Agreements' were signed with the ten CEECs, all of which later presented their applications for membership to the European Commission. The dates are as follows:

\section{Europe Agreements :}

- 31.12.1993 - Europe Agreements are signed between the European Communities and their members states, and Hungary and Poland;

- 31.12.1994 - Europe Agreements are signed between the European Communities and their member states, and Bulgaria, Romania, the Czech Republic, and Slovakia; 
- 12.6.1995 - Europe Agreements are signed between the European Communities and their member states and Estonia, Latvia and Lithuania;

- 10.6.1996 - Europe Agreement is signed between the European Communities and their member states and Slovenia.

Dates of Application to EU membership :

- 1.4.1994 - Hungary presents its application.

- 4.4.1994 - Poland presents its application.

-22.6.1995 - Romania presents its application.

-27.6.1995 - Slovakia presents its application.

-27.10.1995 - Latvia presents its application.

-28.11.1995 - Estonia presents its application.

- 8.12.1995 - Lithuania presents its application.

-16.12.1995 - Bulgaria presents its application.

-17.1.1996 - The Czech Republic presents its application.

-10.6.1996 - Slovenia presents its application.

\section{Criteria for Membership}

The most basic condition of membership to the EU is stated in Article $O$ of the TEU: "Any European state may apply to become a member of the EU". A second condition appears in Article $\mathrm{F}$ of the Treaty which stipulates that the Union consists of democracies and designates respect for fundamental human rights as a precondition for membership. These are the only references to criteria for membership included in the TEU. However, other conditions for membership can be found in other documents both on a general and case-by-case basis. In the conclusions of the European Council held in Maastricht, it is stated that "any European States whose systems of governance are founded on the principle of democracy' may apply to become members of the Union". This is a general condition which concerns all the applicant coun-

1 The concept of democracy is not well defined. There is a reference to it in the Declaration of the Council of Ministers in the Mediterranean enlargement of the EC. In The European Community: The Challenge of Enlargement (RIIA, London, 1992) Anna Michalski and Helen Wallace describe democratic states according to the EC conception as those that organize free and just elections, practise the rule of law and show respect for civil and human rights (p. 34). 
tries. However, in the Commission report on enlargement submitted to the Lisbon European Council in June 1992 which gave priority to the accession of EFTA countries, the conditions for membership involved the special status of these countries. Apart from the adoption of the acquis communautaire and the capacity to implement it, which is a general requirement of accession to the Union, assurance that the neutral status of the concerned countries will not hinder the operation of the common foreign and security policy is sought.

Most recently, the European Council stated the conditions for membership of the EU in the Copenhagen Summit. These are:

1. political criteria for membership :

(stability of institutions guaranteeing) democracy, the rule of law, human rights, and respect for and protection of minorities;

2. economic criteria for membership :

the existence of a functioning market economy;

capacity to cope with competitive pressure and market forces within the Union

3. institutional criteria for membership :

ability to take on the obligations of membership including adherence to the aims of political, economic, and monetary union.

\section{Enlargement in the Light of the Conclusions of European Councils}

In this paper the conclusions of the meetings of the European Council starting from the Dublin European Council in 1990 are taken as indicators of EU policy on enlargement. The reason for this is that European Councils are meetings of heads of state or government of EU member states where the future policy of the Union is set in principle.

\section{Dublin European Council 28 April $1990^{2}$}

The idea of concluding Europe agreements with the CEECs date back to this Summit ${ }^{3}$. At this meeting it was decided to complete the first generation of trade and cooperation agreements signed with the CEECs and negotiate a new generation of association agreements as soon as the economic and political situation became favourable, on condition that democratization and transition to market economies are

2 Bulletin EC 4-1990, points 1. T-I.16, pp. 7-11.

3 At the time of the Dublin European Council, it was the EC not the EU since it preceded the TEU which established the European Union. 
unhindered in the countries concerned. These agreements, later called 'Europe Agreements' would include an institutional framework for political dialogue. In the conclusions of the Presidency, the Council pays tribute to the uniting of Europe "which, having overcome the unnatural divisions imposed on it by ideology and confrontation, stands united in its commitment to democracy, pluralism, the rule of law, full respect for human rights, and the principles of the market economy".

\section{Maastricht European Council 9-10 December 19914}

The European Council gave the green light to the accession of the applicant EFTA countries to the Community, after the conclusion of the negotiations on the Community's own resources and related issues in 1992. It asks the Commission to prepare a report on the situation of the applicant countries and the implication for the Union's future development, to be presented to the Lisbon European Council in 1992.

\section{Lisbon European Council 26-27 June $1992^{5}$}

The report by the Commission on "Europe and the Challenge of Enlargement" was approved and membership negotiations with the applicant EFTA countries were begun during this Summit. It was stated that "the principle of a Union open to European states that aspire to full participation and who fulfill the conditions for membership is a fundamental element of the European construction ${ }^{6 m}$. Concerning the term 'European', the Commission stipulates that the concept combines geographical, historical and cultural elements which all contribute to the European identity. The shared experience of proximity, ideas, values, and historical interaction cannot be condensed into a simple formula, and is subject to review by each succeeding generation. The Commission believes that "it is neither possible nor opportune to establish now the frontiers of the European Union, whose contours will be shaped over many years to comen".

Concerning the enlargement process, the conclusions of the Lisbon European Council stipulate that cooperation with Malta, Cyprus, and Turkey should be intensified on the basis of the relevant association agreements, with particular emphasis on political dialogue and underline that each of these applications must be considered on its merits. It was also agreed to intensify cooperation and political

Bulletin EC 12-1991; points I.1-I.19, pp. 7-12.

Bulletin EC 6-1992, points I.1-I.34, pp. 7-24.

Bulletin EC 6-1992 1.4 p. 10.

Bulletin EC 6-1992, I.4, p. 10. 
dialogue with the CEECs within the framework of the Europe Agreements in an effort to assist them in their preparations for accession to the Union. Here it should be noted that the term 'preparing for accession' is used only concerning the CEECs. The membership applications of Cyprus and Malta are also mentioned.

Turkey is dealt with under a separate heading. The European Council underlines that the Turkish role in the present European political situation is of the greatest importance and that there is every reason to intensify cooperation and develop relations with Turkey in line with the prospect laid down in the Association Agreement of 1964 including a political dialogue at the highest level. The Commission, and the Council are given the task of working on the intensification of cooperation and development of relations with Turkey in the coming months. However, there is no reference to the membership application or preparation for accession in the case of Turkey. This observation is valid for the statements and conclusions of the other European Council meetings ${ }^{8}$. The customs union, and increased cooperation and dialogue are the terms used when Turkey is the issue. It is not considered in the same category as the CEECs, or Malta and Cyprus, which are seen as future members of the Union in the medium to long term.

\section{Copenhagen European Council 21-22 June $1993^{\circ}$}

The Copenhagen meeting of the European Council is important in that the criteria for membership of the Union specified above were determined during this Summit. It is stated that the associated countries of Central and Eastern Europe may become members of the Union if they so wish, provided they are fit to assume the obligations resulting from membership by satisfying the economic and political conditions required. The message of the European Council is that the EU intends to include these countries in the European integration process. However, they must first improve their economic and political standards before accession. For this purpose the Union will assist them politically and financially by way of;

1- the structured dialogue between the CEECs and Community institutions in the form of regular meetings on a broad range of topics;

2- opening up of Community markets to products originating from the CEECs and the development of trade among these countries, and between these countries and their traditional trading partners;

8 This observation is a result of the study of the condusions of European Council meetings starting with the Maestricht European Council of 1991.

9 Bulletin EC 6-1993, points 1.1-1.42, pp. 7-23. 
3- aid to the CEECs through the PHARE programme, financing of transEuropean network projects involving the CEECs under the temporary lending facility of the European Investment Bank;

4- opening up of further Community programmes to the CEECs;

5- approximation of laws in the CEECs to the Community legislation especially concerning competiution rules, protection of workers, the environment and consumers.

Corfu European Council 24-25 June 1994 ${ }^{10}$

The Acts of Accession with Austria, Sweden, Finland and Norway" were signed at the Corfu meeting of the European Council which follows the membership applications of Hungary and Poland. At the Corfu meeting the Council also announced that the next phase of enlargement will involve Cyprus and Malta noting that any solution of the Cyprus problem must respect the sovereignty, independence, territorial integrity, and unity of the island in accordance with the relevant UN resolutions and high-level agreements.

The European Council underlines the importance of the conclusion of the 1996 IGC negotiations beiore enlargement takes place, since the instifutional amendments should be completed to ensure the proper functioning of the Union with 20 and possibly 28 Member States. The implementation of the Europe agreements and the decisions taken in Copenhagen constitute the essential conditions for the accession of the CEECs to the EU.

\section{Essen European Council 9-10 December $1994^{12}$}

At the Essen Summit the heads of state and government of the member states met the heads of state and government and the foreign ministers of the Central and Eastern European countries (CEEC) which are associated with the EU through the Europe Agreements and held an exchange of views with them on the strategy for accession of these states to the Union. The European Council, while noting that the challenge of enlargement is lying before the EU, included in its priority guidelines; "ensuring the lasting peace and stability of the European continent and neighboring regions by preparing for the future accession of the associated countries of Central and Eastern Europe and developing in parallel the special relationship of the Union to its other neighbors, particularly the Mediterranean countries.

11 Nonway later rejected EU membership by a referendum.

12 Bulletin EU 12-1994, points I.1-I.55, pp. 7-27. 
The European Council decided to give a new impetus to the process of further preparing the associated CEECs for accession, noting that the institutional conditions for ensuring the proper functioning of the Union must be created at the 1996 IGC, before accession negotiations begin. In line with this attitude, it adopted a comprehensive strategy for integrating the CEECs to the EU and asked the Commission and the Council to work towards the conclusion of Europe agreements with the Baltic States and Slovenia. At the political level the pre-accession strategy for the CEECs involves the creation of "structured relations" between the CEECs and EU institutions for the purpose of building mutual trust and providing a framework for dealing with issues of common interest.

The key element in the pre-accession strategy is the preparation of the CEECs for integration into the internal market of the Union which involves the development of infrastructure, cooperation in fields having a trans-European dimension including energy, environment, transport, science and technology, common foreign and security policy, and justice and home affairs. In this context, the European Council asked the Commission to prepare a White Paper together with a detailed analysis of the effects of enlargement concerning the Union's current policies and their future development, and a study of the means of developing relations in the agricultural sector.

\section{Cannes European Council 26-27 June 1995 ${ }^{13}$}

The Cannes European Council confirmed that the membership negotiations with Cyprus and Malta will start six months after the conclusion of the IGC, taking into account the outcome of the Conference. The European Council notes that the pre-accession strategy adopted by the Essen European Council, the main instruments of which are the Europe agreements and the structured dialogue took off in the first half of 1995. It adds that six Europe agreements are in force while the Europe agreements with the Baltic States of Latvia, Lithuania and Estonia have been signed on 12 June 1995.

\section{Madrid European Council 15-16 December $1995^{14}$}

The European Council stressed the "absolute equality of treatment" between candiate countries and called on the Commission to submit its opinions after the end of the IGC; towards the end of 1997. On the basis of these opinions the Council will take the decision to begin the initial accession negotiations, in principle at the same time as those with Cyprus and Malta. 
In this Summit, the political agenda of the EU for the next five years was set:

1- carrying out the adjustments to the TEU;

2- making the transition to a single currency in line with the timetable and conditions set;

3- preparing for and carrying out the enlargement negotiations with the associated countries of Central, Eastern, and Southern Europe which have applied for membership of the EU;

4- determining, in parallel, the financial perspective beyond 31 December 1999;

5- contributing to establishing the new European Security architecture;

6- actively continuing the policy of dialogue, cooperation and association already under way with the Union's neighboring countries, in particular with Russia, Ukraine, Turkey and the Mediterranean countries.

It is observed that Turkey is not taken into account as a future member of the EU but as a neighboring country with which good relations based on dialogue, cooperation and association should be developed.

\section{External Human Rights Policy of the EU}

In recent years, human rights have emerged as a main theme in the external political relations of the EU. As mentioned above, the observance of human rights is one of the preconditions of membership of the Union. Moreover, the EU, particularly through the European Parliament, keeps a watchful eye on the development of human rights throughout the world.

Respect for Human Rights was not included in the preamble or the text of the Treaty of Rome. The Single European Act of 1987 made a reference to human rights in the preamble: "Determined to work together to promote democracy on the basis of the fundamental rights recognized in the constitutions and laws of the Member States, in the Convention for the Protection of Human Rights and fundamental rights and the European Social Charter, notably freedom, equality and social justice ... aware of the responsibility incumbent upon Europe to ... display the principles of democracy and compliance with the law and with human rights to which they are attached...".

With the coming into force of the TEU the preference of the Union for the observance of human rights and democracy is for the first time included in the text of the Founding Treaties. This development is an indicator that the Union, which has 
formerly been an economic endeavor, is turning into a political entity as well. As mentioned above Article $F(2)$ states that "the Union shall respect fundamental rights as guaranteed by the European Convention for the Protection of Human Rights and Fundamental Freedoms signed in Rome on 4 November 1950 and as they result from the constitutional traditions common to the Member States, as general principles of Community law".

The TEU also established human rights and democracy as a main principle of the Union's common foreign and security policy. Article $\mathrm{J}$-1(2) stipulates that it is one of the main objectives of the common foreign and security policy to develop and consolidate democracy and the rule of law, and respect for human rights and fundamental freedoms. Article 130u(2) of the Treaty regarding the Union's development cooperation policy -involving aid to third countries- establishes the observance of human rights and democracy as an underlying aim of the EU's development policy: "EC development cooperation policy shall contribute to the general objective of developing and consolidating democracy and the rule of law and to that of respecting human rights and fundamental freedoms".

In the Luxembourg European Council of June 1991 the heads of State and Government of the Member States adopted a declaration on human rights. In the declaration reference is made to the 1986 declaration of Foreign Ministers of the Community on Human Rights (21 July 1987). It is confirmed that respecting, promoting and safeguarding human rights is an essential part of international relations and one of the corner-stones of European cooperation as well as of relations between the Community and its Member States and other countries. The Community and its member states undertake to pursue their policy of promoting and safeguarding human rights and fundamental freedoms throughout the world... They recall that the different ways of expressing concern about violations of rights as well as requests designed to secure those rights, cannot be considered as interference in the internal affairs of a State, and constitute an important and legitimate part of their dialogue with third countries. For their part, the Community and its Member States will continue to take up violations wherever they occur ${ }^{\text {t5 }}$.

The Lisbon European Council of 1992 gives its support to the consolidation of democratic institutions, rule of law and respect for human rights, including the rights of minorities, and the inviolability of borders, in the CEECs. In the report to the European Council in Lisbon on the likely development of the common foreign and security policy, strengthening democratic principles and institutions, and respect for human and minority rights are cited among the specific objectives of the common 
foreign and security policy especially with regard to chosen areas which are Central and Eastern Europe, in particular the Commonwealth of Independent States and the Balkans, and the Mediterranean, in particular the Maghreb, and the Middle East. ${ }^{16}$

The position of the EU regarding the Euro-Mediterranean Conference in Barcelona involved a detailed explanation of what is meant by human rights, democracy and the rule of law in the relations of the EU with the countries of the Mediterranean basin, including Turkey. ${ }^{17}$ :

1) Respect for the basic texts: A commitment by the partners to act in accordance with the UN Charter and the Universal Declaration of Human Rights, as well as the obligations arising from the international declarations and agreements in this field by which they are bound..$^{18}$

2) Rule of law: Each partner should be able to commit itself to the development of the rule of law and democracy in its internal political system (free and regular elections to governing and representative bodies, independent judiciary, balance of powers and good governance), with the partners recognizing at the same time the right of each of them to choose and freely develop its own political, sociocultural and economic system, provided it complies with commonly agreed international standards concerning human rights.

3) Fundamental freedoms: (i). A commitment by each partner to take practical steps to ensure the effective exercise of fundamental freedoms, on the basis of the undertakings entered into by the partners in the previous two paragraphs, including freedom of expression, freedom of association for peaceful purposes and freedom of thought, conscience and religion. (ii) A commitment by the partners to give favourable consideration to the possibility of exchanging information and responding to any requests for information made to them by the partners on questions in connection with human rights and fundamental freedoms.

4) Pluralism and tolerance: A commitment by each partner to respect diversity and pluralism in society. A call for the promotion of tolerance between different groups in society and for resistance to manifestations of intolerance, especially ra-

17 Bulletin EU 6-1995 point I.50, p. 23-24.

18 Since most of the Mediterranean countries involved in the Euro-Mediterranean partnership are not members of the Council of Europe or the Organization for Security and Cooperation in Europe the lexts adopted by these regional organizations are not cited here. However it should be noted here that these regional arrangements for the protection of human rights are more effective than the UN framework. It should also be emphasized that Turkey is a part of the European human rights regime. 
cism and xenophobia. Action against terrorism will be all the more effective if it observes the rule of law and the principles of human rights and is coupled in the longer term with policies for specific action to deal with the underlying causes. The partners could thus stress the importance of proper education in the matter of human rights and fundamental freedoms.

5) Human rights: A commitment by the partners to respect human rights and fundamental freedoms and the exercise of such rights and freedoms, both individually and together with other members of the same group without any discrimination on the grounds of race, nationality, language, religion, or sex.

In the Presidency's progress report on the IGC included in the conclusions of the Florence European Council in June 1996, it is once more stated that "as the Union is composed of States whose systems of government are founded on the principles of composed of States whose systems of government are founded on the principles of freedom, democracy, respect for human rights and the rule of law, the accession of any new State should be conditional on it being established that that State complies with these principles" ${ }^{\prime \prime}$.

The Inclusion of Respect for Democratic Principles and Human Rights in the Agreements With Third Countries

The Commission communication of 23 May 1995 stipulates that the Commission plans to include in all new agreements concluded by the Community with nonmember countries a reference to the observance of human rights which would make it possible for the parties to intervene and take action in case of violations of human rights. The reference to human rights consists of the following ${ }^{20}$ :

1) in the preamble: pertinent references to respect for human rights in general and to universal and/or regional instruments;

2) in the body of the agreement: an Article $X$ defining democratic principles and fundamental human rights as an 'essential element' of the agreement; an Article $Y$ on non-execution, in cases of breach of an essential element of the agreement, which allows the parties to take appropriate measures after consulting the Association or Cooperation Council, except in cases of special urgency;

3) annexed to the agreement: two declarations interpreting Article $Y$, defining the terms 'cases of special urgency' and 'appropiate measures'. 
In response to this Communication the Council approved on May 29 a suspension mechanism to be included in Community agreements with non-member countries to enable the Community to react immediately in the event of violation of essential aspects of those agreements, particularly human rights ${ }^{21}$. Again following this communication the European Parliament adopted a resolution on 20 September 1995 calling for the inclusion of respect for democratic principles and human rights in the Community's agreements with third countries ${ }^{22}$.

The Communication From the Commission on the EU and the External Dimension of Human Rights Policy: From Rome to Maastricht and Beyond

This document which sets out the human rights policy of the EU in the external sphere is divided into two parts:

The first part summarizes the standing of the EU in the international arena by identifying the main platforms concerning human rights, namely the UN, the Organization for Security and Cooperation in Europe, and the Council of Europe as well as the main principles, activities and instruments regulating human rights. The Union's commitment to the work of these institutions, and the internationally acknowledged principles and instruments is emphasized. The Commission refers to three principles arising from the Universal Declaration of Human Rights and confirmed at the world human rights conference organized in Vienna in June 1993. These principles "form the keystone of the international system for the protection of human rights :

1) Universality: no provision of a national, cultural or religious nature can override the principles enshrined in the Universal Declaration of Human Rights,

2) Indivisibility: no discrimination between civil and political rights, and economic, social, and cultural rights,

3) Interdependence between human rights, democracy and development: This involves a new definition of development focused on man as a holder of human rights and the beneficiary of the development process.

According to the Commission these principles lead to the following propositions:

- the strict, complementary link between human rights and democracy: Democracy is a necessary condition for the exercise of human rights; and human rights are a prerequisite for the existence of democracy. 
- the relativity of the principle of non-interference: Expressing concern about violations of human rights in a third country, and requests designed to secure those rights cannot be considered as interference in the internal affairs of a state.

The Commission's priority areas of activity are stipulated as follows :

- supporting the transition to democracy, including the holding of free and fair elections;

- promoting and consolidating the rule of law by supporting and strengthening the independence of the judiciary, supporting the activities of parliaments and other democratically elected bodies, and supporting institutional and legislative reforms,

- supporting local, national, and regional institutions involved in the protection or promotion of human rights, including ombudsmen and others in similar positions,

- promoting a pluralist civil society by strengthening the appropriate bodies, including NGOs,

- promoting independent, pluralist, and responsible media through support for freedom of expression and press freedom,

- supporting education, training and awareness campaigns in the field of human rights,

- promoting equal opportunities and non-discrimination,

- promoting transparency and good governance, supporting campaigns against corruption,

- supporting confidence-building measures aimed at restoring peace,

- supporting national efforts to make the armed forces accountable to civil authority and to establish a clear division of the roles of the army and the police; human rights training and information for members of the army and the police;

- protecting vulnerable groups, in particular children, women, victims of torture, violence or fighting, migrants, refugees and displaced people;

- protecting ethnic, religious and linguistic minorities, their rights and cultures; and,

- protecting indigenous peoples, their rights and cultures.

The Community financed projects aimed at improving the human rights situation in third countries pursue the objectives of consolidating the rule of law, supporting the transition to democracy and promoting the role of bodies ensuring a pluralist society, including NGOs. The target groups are groups that need special protection, women, children, national minorities, indigenous peoples, and victims of 
torture, and the priority target groups for awareness campaigns are journalists, judicial officers, and police personnel.

The second part deals with the future efforts the Union will undertake in the field of human rights. The Commission draws attention to the impact of human rights on international and regional peace and security and on the political stability, social and economic development and general situation of individual countries. This approach highlights the importance of preventive measures and the development of a multi-dimensional overall strategy including human rights, security, development and the environment with particular emphasis on crisis prevention and electoral assistance. In addition the Commission aims at increasing the consistency and impact of EU measures and instruments to protect and promote fundamental human rights. For this purpose it stipulates a strategy for effective action in this field to improve consistency, quality, impact and visibility, coupled with the upgrading and extension of EU instruments.

\section{The Position of the European Parliament in the Field of Human Rights}

The European Parliament (EP) is one of the key players in the EU, working towards the furtherance of the cause of human rights in relations with third countries. This is evident from the numerous resolutions the EP adopts concerning violations of human rights in different parts of the world. The position of the EP concerning the EU external human rights policy can be discerned in the Resolution on human rights throughout the world in 1995/96 and the Union's human rights policy ${ }^{23}$.

In the Resolution reference is made to "the resurgence of ethnic regional conflicts such as those in the former Yugoslavia, Chechnya, Rwanda, Burundi, Zaire, that affecting the Kurdish people, ... continuing violations of human rights in East Timor by the Indonesian forces, ... continuing use of such reprehensible practises as the death penalty, torture and inhuman or degrading treatment in places of imprisonment, or the forced displacement of peoples, ... the slow pace of human rights reforms in certain countries undergoing transition in Central Europe and, even more so, in Eastern Europe, ... resurgence of fanaticism and political or religious intolerance.... The EP then draws attention to the dangers of declarations on human rights not being followed up by practical measures and to the ambiguity surrounding the concept of human rights. Consequently, it calls for a number of concepts related to human rights to be clearly defined. These are the scope of the principles of universality and indivisibility, the respective places of civil and political rights, economic and social rights, cultural rights, the rights of people belonging to minority groups, in 
particular national minorities, the rights of refugees, women's rights, children's rights, the right to a healthy environment, the rights of the individual in relation to life sciences, etc., the links between democracy and human rights, and the relationship between humanitarian action and law, and human rights.

The Resolution also calls for agreements concluded between the Union and third countries not to be approved if the human rights situation is not satisfactory. It goes on to assert that the main rule for agreements concluded between the Union and third countries must be that the country meets the Union's criteria concerning human rights. Consequently it calls on the Commission to submit a proposal for a procedure which would make it possible to take action in case of human rights violations in third countries which have concluded an agreement with the EU. In this way the EP intends to set up a mechanism for the enforcement of human rights at least in countries which have contractual relations with the EU.

The resolution notes that the policy of giving unconditional development aid to third countries has been replaced by the policy of conditionality of aid introduced by the Council Decision of November 1991. The EP wants the new policy to be specifically defined making reference to the ambiguity this situation causes in relation to agreements with third countries "such as the partnership agreement with Russia and the customs union agreement ${ }^{24}$ with Turkey". Here we see the uneasiness of the EP concerning the customs union with Turkey. Although the EP ratified the customs union decision of the Turkey-EC Association Council, it seems that most members of the EP regret the ratification due to the poor improvement of the human rights situation in Turkey. They feel they have been deceived by Turkish politicians who have made many promises to secure the approval of the EP.

\section{Turkey - EU Relations and the Issue of Human Rights}

The Commission Opinion on Turkey's request for accession to the Community, which was prepared in response to the Turkish application for membership of the EC in 1987, expresses a negative view on the case. The Commission states that although there have been improvements in the parliamentary democracy in Turkey since the military coup in 1980, the legislation is still marked by the legacy of the closed regime. Moreover, the situation of human rights and the respect for the identity of minorities have not yet reached the level required in a democracy. At the time Turkey was not seen as possessing the necessary preconditions of respect for human rights and minority rights required for membership of the Community. 
The situation has changed very little since then. Turkey is still accused of human rights violations, in particular by the EP. Although a 'democratization package' has been adopted by the Turkish Grand National Assembly before the approval of the customs union by the EP in December 1995, systematic violations of human rights continue. In a recent resolution, the EP expresses its concern about the freedom of the press and human rights in Turkey ${ }^{25}$.

In the report on developments in relations with Turkey since the coming into force of the customs union, the Commission expresses its concerns about human rights violations and the pace of democratization in Turkey ${ }^{26}$. The Commission aims to steer a middle-way in respect of Turkey's human rights record. It cites the violations as well as the developments and in this way tries to counterbalance the often aggressive tone of the EP's denunciations regarding the situation of human rights in Turkey. The Commission emphasizes the ineffectiveness of the reforms undertaken by the Turkish government in 1995, and points to the fact that despite the amendment of Article 8 of the anti-terrorism law, Article 8 continued to be used against treedom of expression (the cases of Yaşar Kemal, Özcan Sapan, a publisher, and a former member of parliament Sirrı Sakık are cited). Torture, especially during periods of custody -the torture of the youths arrested in Manisa for their alleged membership of an illegal leftist party is cited, ill-treatment of prisoners, disappearances and extrajudicial executions -the murder of Metin Göktepe, a journalist is cited-continue to take place, although those responsible for torture are increasingly brought before the courts. The maximum duration of custody which is 15 days under the anti-terrorism law and 30 days under the state of emergency are not yet reduced. The situation in prisons, the state of emergency in the south-east provinces, pressure on nongovernmental organizations, and the trials of members of Hadep are followed up under separate headings.

In its conclusions, the Commission underlines the lack of progress concerning democratization and human rights and points to the importance of "decisive and speedy action by the Turkish government and parliament to strengthen the freedom of the individual and respect for fundamental rights ${ }^{227}$ in Turkey's relations with the EU. The Commission, while expressing its understanding concerning the situation in the south-east of Turkey, notes that "the fight against terrorism must be conducted in a spirit of respect for the fundamental values of democracy and human rights... Action against terrorism must not stand in the way of the recognition of the rights, par- 
ticularly the cultural rights, of Turkish citizens of Kurdish origin whilst still respecting Turkey's unity and integrity ${ }^{\text {228 }}$.

According to newspaper reports, the latest Commission report on the applicant countries, prepared upon the request of the Apeldoorn meeting of the Council of Foreign Ministers, is pessimistic about the political situation in Turkey. In the study, which makes a comparison between the applicant countries, Turkey scores low on the political front due to problems concerning the situation of human rights, the dominant position of the Armed Forces in the country's political life, and the unresolved disputes with Greece concerning the Aegean and Cyprus. The Commission states that Turkey is not yet fit to be a member of the $\mathrm{EU}^{22}$. The report is to be presented to the General Affairs Council on July 221997.

\section{Conclusion}

Respect for Human Rights emerges as a vital precondition of membership to the EU. In this regard, the future membership of Turkey is dependent upon the termination of its systematic human rights violations. Turkey should make a credible effort to improve the situation. The EU is aware of the current political instability and ambiguity in Turkey. However, this condition cannot be an excuse. The EU will take in a number of countries with lower economic and political standards than the EU average in the near future. The adjustment of these countries to EU mechanisms and policies will place a considerable burden upon the EU. Therefore, the EU will be more hesitant than ever before to include such a country as Turkey with sui generis political problems covering a wide spectrum from identity crisis, and the fight against terrorism to a confrontation between political Islamists and an alliance of the military and secularists.

In the last analysis, the incidence of human rights violations is an indicator of deeper structural problems in Turkey, such as low living standards, the heritage of a particular political culture, lack of democratic imperatives, and low level of political participation through civil organizations. It is hoped that in parallel with the transformation of the society towards democratization and strenghtening of civil initiatives, the problems concerning respect for human rights will become less acute. 


\section{BIBLIOGRAPHY}

Michalski, Anna; Helen Wallace, The European Community: The Challenge of Enlargement, Royal Institute of Intemational Affairs, London, 1992.

General Report of the EU, 1996, point 39, p. 27.

Bulletin of the European Communities / European Union :

4-1990, points I.1-I.16, pp. 7-11.

6-1991, point I.45, pp. 17-18.

12-1991, points I.1-I.19, pp. 7-12.

6- 1992, points I.1-I.34, pp. 7-24.

6- 1993, points I.1-1.42, pp. 7-23.

6- 1994, points I.1-1.29, pp. 7-20.

12- 1994, points I.1-1.55, pp. 7-27.

5- 1995, point 1.2.2-1.2.3, p. 9.

6- 1995 points I.1-1.58, pp. 9-32.

12- 1995, points I.1-I.111, pp. 9-51.

6- 1996, point l.65, p. 43.

Official Joumal of the European Communities

C20, 20.1.1997, pp. 161-170.

C20, 20.1.1997, pp. 143-144.

COM (96) $491,30.10 .1996$

Yeni Yüzyll, 14.6.1997, “AB’den Eşit Muamele Isteyen Ankara'ya Şok”, p. 15. 